\title{
Cost-effectiveness of antiviral therapy during late pregnancy to prevent perinatal transmission of hepatitis B virus
}

Wenjun Wang, Jingjing Wang, Shuangsuo Dang, Guihua Zhuang

Background Hepatitis B virus (HBV) infections are perinatally transmitted from chronically infected mothers. Supplemental antiviral therapy during late pregnancy with lamivudine (LAM), telbivudine (LdT), or tenofovir (TDF) can substantially reduce perinatal HBV transmission compared to postnatal immunoprophylaxis (IP) alone. However, the costeffectiveness of these measures is not clear. Aim This study evaluated the costeffectiveness from a societal perspective of supplemental antiviral agents for preventing perinatal HBV transmission in mothers with high viral load ( $>6 \log _{10}$ copies $/ \mathrm{mL}$ ). Methods A systematic review and network meta-analysis were performed for the risk of perinatal HBV transmission with antiviral therapies. A decision analysis was conducted to evaluate the clinical and economic outcomes in China of four competing strategies: postnatal IP alone (strategy IP), or in combination with perinatal LAM (strategy LAM+IP), LdT (strategy LdT+IP), or TDF (strategy TDF+IP). Antiviral treatments were administered from week 28 of gestation to 4 week after birth. Outcomes included treatment-related costs, number of infections, and quality-adjusted life years (QALYs). One-and two-way sensitivity analyses were performed to identify influential clinical and cost-related variables. Probabilistic sensitivity analyses were used to estimate the probabilities of being cost-effective for each strategy. Results LdT+IP and TDF+IP averted the most infections and HBV-related deaths, and gained the most QALYs. IP and TDF+IP were dominated as they resulted in less or equal QALYs with higher associated costs. LdT+IP had an incremental $\$ 2,891$ per QALY gained (95\% confidence interval $-\$ 932 \sim \$ 20,372$ ) compared to LAM+IP (GDP per capita for China in 2013 was $\$ 6,800)$. One-way sensitivity analyses showed that the costeffectiveness of LdT+IP was only sensitive to the relative risk of HBV transmission comparing LdT+IP with LAM+IP. Probabilistic sensitivity analyses demonstrated that LdT+IP was cost-effective in most cases across willingness-to-pay range of $\$ 6,800 \sim$ $\$ 20,400$ per QALY gained. Conclusions For pregnant HBV-infected women with high levels of viremia, supplemental use of LdT during late pregnancy combined with postnatal IP for infants is cost-effective in China. 
4 Authors: Wenjun Wang ${ }^{1,2}$, Jingjing Wang $^{3}$, Shuangsuo Dang ${ }^{1,2, *}$, Guihua Zhuang $^{2}$

$6{ }^{1}$ Department of Infectious Diseases, Second Affiliated Hospital of Xi'an Jiaotong University,

$7 \quad$ Xi'an 710004, China

$8 \quad 2$ Department of Epidemiology and Biostatistics, Medical School of Xi'an Jiaotong University,

$9 \quad$ Xi'an 710061, China

$10{ }^{3}$ Department of Pediatrics, Second Affiliated Hospital of Xi'an Jiaotong University, Xi'an

11710004, China

12

13 * To whom correspondence should be addressed: Shuangsuo Dang, Director of Department of

14 Infectious Diseases, Second Affiliated Hospital of Xi'an Jiaotong University, 157 Xiwu Road,

15 Xi'an 710004, China; Email: dangss212@yahoo.com

16

17 


\section{Abstract}

19

20

21

\section{Background}

Hepatitis B virus (HBV) infections are perinatally transmitted from chronically infected mothers.

Supplemental antiviral therapy during late pregnancy with lamivudine (LAM), telbivudine (LdT), or tenofovir (TDF) can substantially reduce perinatal HBV transmission compared to postnatal immunoprophylaxis (IP) alone. However, the cost-effectiveness of these measures is not clear.

\section{Aim}

This study evaluated the cost-effectiveness from a societal perspective of supplemental antiviral agents for preventing perinatal HBV transmission in mothers with high viral load $\left(>6 \log _{10}\right.$ copies/mL).

\section{Methods}

A systematic review and network meta-analysis were performed for the risk of perinatal HBV transmission with antiviral therapies. A decision analysis was conducted to evaluate the clinical and economic outcomes in China of four competing strategies: postnatal IP alone (strategy IP), or in combination with perinatal LAM (strategy LAM+IP), LdT (strategy LdT+IP), or TDF (strategy TDF+IP). Antiviral treatments were administered from week 28 of gestation to 4 week after birth. Outcomes included treatment-related costs, number of infections, and qualityadjusted life years (QALYs). One-and two-way sensitivity analyses were performed to identify influential clinical and cost-related variables. Probabilistic sensitivity analyses were used to estimate the probabilities of being cost-effective for each strategy.

\section{Results}


39 LdT+IP and TDF+IP averted the most infections and HBV-related deaths, and gained the most

40 QALYs. IP and TDF+IP were dominated as they resulted in less or equal QALYs with higher

41 associated costs. LdT+IP had an incremental \$2,891 per QALY gained (95\% confidence interval

42 -\$932 \$20,372) compared to LAM+IP (GDP per capita for China in 2013 was \$6,800). One-

43 way sensitivity analyses showed that the cost-effectiveness of LdT+IP was only sensitive to the

44 relative risk of $\mathrm{HBV}$ transmission comparing LdT+IP with LAM+IP. Probabilistic sensitivity

45 analyses demonstrated that LdT + IP was cost-effective in most cases across willingness-to-pay

46 range of $\$ 6,800 \sim \$ 20,400$ per QALY gained.

\section{Conclusions}

For pregnant HBV-infected women with high levels of viremia, supplemental use of LdT during late pregnancy combined with postnatal IP for infants is cost-effective in China. 


\section{Abbreviations:}

55 ALT: alanine aminotransferase

56 CI: confidence interval

57 HBeAg: hepatitis B e antigen

58 HBIG: hepatitis B immunoglobulin

59 HBsAg: hepatitis B surface antigen

60 HBV: hepatitis B virus

61 ICER: incremental cost-effectiveness ratio

IP: immunoprophylaxis

63 LAM: lamivudine

64 LdT: telbivudine

65 OR: odds ratio

66 QALY: quality-adjusted life year

67 RR: relative risk

68 TDF: tenofovir

69 


\section{Introduction}

Chronic hepatitis B virus (HBV) infection is a serious public health problem in China that affects $\sim 93$ million people (7.18\% of the population), representing a quarter of all HBV-infected people worldwide. ${ }^{1} \mathrm{HBV}$-related liver diseases and liver cancer are responsible for up to 300,000 deaths each year. ${ }^{2}$ The economic burden of HBV infections in China alone is estimated to be in excess of 80 billion US dollars annually. ${ }^{3}$

The predominant mode of HBV infection involves perinatal transmission from chronically infected mothers to their infants. ${ }^{4-6}$ This can be suppressed by passive immunization with hepatitis B immunoglobulin (HBIG) administered within 12 hours of birth and active immunization with a three-dose HBV vaccination series. ${ }^{7}$ The success of these immunoprophylaxis (IP) measures is demonstrated by the low prevalence of hepatitis B surface antigen (HBsAg) in children under five years of age in mainland China and the substantial reduction in HBV infection in Taiwan. ${ }^{1,8}$

Despite these encouraging results, a proportion of infants still test positive for the HBsAg. ${ }^{7}$ The mother's viral load in serum is an important contributing factor, as infants born from $\mathrm{HBeAg}$ (hepatitis $\mathrm{B}$ e antigen)-positive mothers with high levels of viremia are at greatest risk for perinatal transmission. ${ }^{9-11} \mathrm{HBV}$ replication in pregnant mothers can safely be suppressed with nucleos(t)ide analogues, such as lamivudine (LAM), telbivudine (LdT), and tenofovir(TDF), ${ }^{12-15}$ which reduce perinatal transmission when administered during the third trimester. ${ }^{16-19}$ Previous studies indicate that supplemental prenatal use of LAM is cost-effective compared with postnatal IP only. ${ }^{20-23}$ Although LdT and TDF are more potent, the costs for these treatments are higher. 
91 Therefore, the purpose of this study was to examine the cost-effectiveness of these treatments

92 from a societal perspective for prevention of perinatal transmission of HBV in China.

\section{Materials and Methods}

\section{Model and strategies}

Decision analysis software (TreeAge Pro 2012, TreeAge Software Inc., Williamstown, MA,

USA) was used to estimate the clinical and economic outcomes for a hypothetical cohort of

10,000 pregnant Chinese women chronically infected with HBV. All women were considered

positive for $\mathrm{HBeAg}$ with serum levels of $\mathrm{HBV}-\mathrm{DNA}>6 \log _{10}$ copies/mL. The following four

strategies were compared: 1) postnatal IP for the infants only; 2) perinatal LAM and postnatal IP

(LAM+IP); 3) perinatal LdT and postnatal IP (LAM+IP); and 4) perinatal TDF and postnatal IP

(TDF+IP) (Fig. 1). Perinatal antiviral treatments were administered to the pregnant women

beginning from week 28 of gestation to 4 week after birth. Perinatal transmission of HBV was defined as HBsAg positive of infants 6 months after birth.

If infants were infected by $\mathrm{HBV}$, their lifetime clinical and economic outcomes were simulated using a Markov model based on a previous study ${ }^{24}$ (Fig. S1). This model was composed of the following eight states: normal alanine aminotransferase (ALT), elevated ALT, durable response, compensated cirrhosis, decompensated cirrhosis, hepatocellular carcinoma, 


\section{Systematic review and meta-analysis}

113 A systematic review and network meta-analysis were performed to calculate odds ratios (ORs)

114 for perinatal transmission of HBV; see Fig. S2 and Article S1. Briefly, PubMed, Embase,

115 Cochrane Central Register of Controlled Trials, and the Chinese Biomedical Literature Database

116 were searched to identify controlled studies addressing prenatal antiviral therapy. Although a

117 number of studies evaluating LAM+IP or LdT+IP versus IP were identified, very few compared

$118 \mathrm{LAM}+\mathrm{IP}$ and LdT+IP directly (Fig. S3 and Table S1). ${ }^{26-45}$ As a result, a network meta-analysis

119 was deemed more suitable. ${ }^{46}$ All clinical estimates and their ranges are shown in Table 1.

120 The reported ORs of HBV transmission were 0.21 (95\% confidence interval [CI]: $0.12-0.38)$

121 for $\mathrm{LAM}+\mathrm{IP}$ versus IP, and 0.55 (95\% CI: 0.24-1.29) for LdT+IP versus LAM+IP. The corresponding relative risks (RRs) of HBV transmission were then calculated using the formula:

$\mathrm{RR}=\mathrm{OR} /\left[\left(1-\mathrm{P}_{0}\right)+\left(\mathrm{P}_{0} \times \mathrm{OR}\right)\right]$, where $\mathrm{P}_{0}$ indicates the incidence of $\mathrm{HBV}$ transmission in the IP

(for $\mathrm{LAM}+\mathrm{IP}$ versus IP) or LAM+IP (for $\mathrm{LdT}+\mathrm{IP}$ versus $\mathrm{LAM}+\mathrm{IP}$ ) groups based on the

weighted mean by the study sample size; $\mathrm{P}_{0}=0.117$ and 0.027 , respectively. Furthermore, the $95 \%$

CIs of the ORs were transformed to RR form for sensitivity analyses. An equal risk of HBV

transmission was assumed for TDF+IP and LdT+IP in the base-case analyses based on the

antiviral potencies of TDF and LdT and two small-sized studies. ${ }^{16,19,47,48}$ For sensitivity

analyses, it was assumed that the risk for TDF+IP was not likely to be less than half of that for

LdT + IP. The range of transmission rates for the IP group reported in each study were recorded and included in sensitivity analyses.

Although IP is the current recommendation in China to interrupt perinatal hepatitis B 
133 transmission, ${ }^{49}, 50$ the compliance rate varies across regions. ${ }^{51-53}$ Using estimates of the

134 proportions of children receiving HBV vaccine plus HBIG in three regions reported by Cui et

$135 a l .,^{51}$ the overall proportion was calculated by weighting the sample size from each region.

136 The high reported adherence to antiviral treatment in pregnant mothers ${ }^{16,26-45}$ is likely due to

137 a variety of factors, including a strong desire to protect their infants against HBV, the safety of

138 the antiviral agents, short duration of treatment, and low incidence of drug resistance. ${ }^{12-15,54,55}$

139 For those who did not fully comply, the risk of HBV transmission was assumed to equal that of

140 IP alone. For mothers who chose antiviral strategies, $100 \%$ coverage of IP for their infants was

141 assumed, regardless of their adherence to antiviral treatment.

142 Under the National Immunization Program, free HBV vaccinations are available to all

143 Chinese infants, covering 97.6\% of infants born from HBsAg-positive mothers in 2009. ${ }^{51}$

144 Therefore, it was assumed that infants who did not receive HBIG at birth were covered by the

145 HBV vaccination. According to a meta-analysis, the risk of HBV transmission with vaccination

146 only is nearly twice that with vaccination plus $\mathrm{HBIG}$ (RR $1.85,95 \% \mathrm{CI}: 1.37-2.44){ }^{7}$

147 We obtained from a published study the natural history estimates of chronic HBV infection 148 and health-state utility weights for calculating quality-adjusted life years (QALYs). ${ }^{24}$ An agespecific death rate table was used to estimate the death probabilities for HBV-infected people without complications and uninfected people. ${ }^{56}$

\section{Costs}

For cost analyses, the costs of HBV-marker tests (inclusive of HBeAg and HBsAg tests), HBV- 
DNA quantification, antiviral drugs, vaccination, and HBIG were included. The actual cost of HBV-DNA quantification for one mother who is going to receive antiviral treatment was calculated as $n+1$ times the cost of one test, where $n$ indicates the ratio of the proportion of mothers with HBV-DNA $<6 \log _{10}$ copies/mL to those with HBV-DNA $>6 \log _{10}$ copies/mL, as previously described. ${ }^{57}$ The cost of only one dose of HBIG was included, as a meta-analysis showed that multiple doses of HBIG are not superior to a single dose of HBIG in preventing perinatal transmission of $\mathrm{HBV}^{7}$

The costs of vaccination and HBIG were obtained from published studies, ${ }^{58,}{ }^{59}$ LAM and LdT from Price Bureau of Shaanxi Province, ${ }^{60}$ and TDF from Kangdele Pharmacy. ${ }^{61}$ The costs for HBV-related diseases incorporated direct medical costs and non-medical costs for physician visits, medications, lab tests, and transportation, and indirect costs for work loss, as reported in published studies. ${ }^{62,63}$

All cost estimates were converted to US Dollars according to the 2013 conversion rate (1 US Dollar $=6.13$ Chinese Yuan) using the medical care component of the Consumer Price Index and discounting costs and QALYs to 2013 amounts at a rate of 3\% per year. ${ }^{64}$ All cost estimates and their ranges are listed in Table 2.

\section{Outcomes}

Short-term outcomes evaluated clinical and economic outcomes during the period from the initiation of the strategies to 6 months after birth, including the number of infections, incremental infections averted, prophylaxis costs, incremental costs, and the corresponding incremental cost- 
175 effectiveness ratio (ICER). Long-term outcomes evaluated lifetime clinical and economic

176 outcomes under four strategies, including HBV-related death, QALYs, incremental QALYs,

177 lifetime costs, incremental lifetime costs, and the corresponding ICER. The ICER was used to 178 compare alternative strategies after eliminating those that were dominated (more costly and less

179 effective). It was calculated as the incremental cost divided by the incremental health benefit (e.g.

180 infections averted and QALYs gained) for one strategy compared to the next less-costly strategy.

181 The cost-effectiveness analyses were conducted from a societal perspective in accordance with

182 the World Health Organization recommendations, and cost-effectiveness thresholds were based

183 on the gross domestic product (GDP) per capita: highly cost-effective (ICER < GDP per capita);

184 cost-effective (GDP per capita $<$ ICER $<3 \times$ GDP per capita); and not cost-effective (ICER >

$1853 \times$ GDP per capita). ${ }^{65}$ The GDP per capita for China in 2013 was approximately $\$ 6,800.64$

\section{Sensitivity analyses}

One-and two-way sensitivity analyses were performed to identify influential clinical and costrelated variables. In addition, a probabilistic sensitivity analysis was conducted based on a second-order Monte Carlo simulation. ${ }^{66}$ All variables from Table 1 that were put into the simulation were assumed to follow a triangle distribution (likeliest, minimum, and maximum values). ${ }^{67}$ A total of 1000 trials were simulated, and cost-effectiveness acceptability curves for competing strategies were constructed.

\section{Results}




\section{Base-case analyses}

197

Antiviral strategies prevented more perinatal hepatitis B transmissions than IP alone. The fewest number of infections occurred with LdT+IP and TDF+IP (Fig. 2). Short-term cost was increased with effectiveness, except for TDF+IP, which was equally as effective as LdT+IP, but at more than twice the cost (Table 3).

In the long-term, the more effective strategies resulted in fewer instances of hepatocellular carcinoma and HBV-related death, and increased the QALYs (Table 4). IP and TDF+IP were dominated because they resulted in the same or fewer QALYs but at a comparatively higher cost. LdT+IP had an incremental \$2,891 per QALY gained $(95 \%$ CI $-\$ 932 \sim \$ 20,372)$ compared to $\mathrm{LAM}+\mathrm{IP}$.

\section{Sensitivity analyses}

One-way sensitivity analyses were performed across the ranges of all clinical and cost-related variables. The cost-effectiveness of LdT+IP was only sensitive to one of them, the RR of HBV transmission in comparison to LAM+IP. If the RR is above 0.92 , LdT+IP would be not costeffective.

cost is doubled and that of LAM halved. When TDF+IP protects more infants than LdT + IP and simultaneously the cost of TDF goes down, TDF+IP may become cost-effective (Fig. S4). With lower transmission risk of TDF+IP compared with LdT+IP, TDF+IP may also become costeffective with changes in additional variables, such as the probabilities of HBV transmission for 
217 competing strategies, the discount rate, the cost of LdT, and the utility weight for the state of 218 chronic HBV infection with normal ALT levels.

219 Acceptability curves constructed from probabilistic sensitivity analyses showed that LdT + IP was highly cost-effective in $89.8 \%$ of the trials under a willingness-to-pay threshold of $\$ 6,800$, and cost-effective in $83.7 \%$ under a threshold of $\$ 20,400$ (Fig. 3). As the price of TDF is likely to change in the near future, acceptability curves were simulated for a series of TDF cost from $\$ 8$ to $\$ 3.6$ daily. As the cost of TDF decreases, TDF+IP would become the most cost-effective strategy (Fig. S5).

\section{Discussion}

Antiviral treatment as prophylaxis for perinatal hepatitis B transmission is recommended in updated guidelines from the European Association for the Study of the Liver, Asian Pacific Association for the Study of the Liver, and the National Institute for Health and Care

Excellence. ${ }^{68-70}$ However, there is no consensus regarding which antiviral agent is most appropriate. Only one agent, LAM, was included in previous cost-effectiveness analyses of highincome areas only. ${ }^{20-23}$ The results of the present analyses confirm that conventional IP alone is not cost-effective under any circumstance, and further demonstrate that supplemental use of LdT is highly cost-effective, and preferable over LAM or TDF in China.

Implementation of the National Immunization Program that provides HBV vaccinations to all neonates and extends HBIG administration to those whose mothers are infected with HBV 
women with a high viral load will have a further impact, not only in terms of health benefits but

also in terms of economic costs. Supplementation of IP with LdT or LAM will dramatically reduce the overall number of HBV infections, and reduce perinatal transmission by at least half.

Thus, one could expect the prevalence of HBV to be $<0.5 \%$ among those at the highest risk for infection, i.e., children under five years of age. The initial additional cost of antiviral treatment will be outweighed by the reduced economic burden of HBV-related diseases.

From a cost-effectiveness perspective, China will benefit from the use of LAM or LdT antiviral strategies to prevent $\mathrm{HBV}$ transmission. Indeed, Chinese hepatologists in tertiary hospitals have been prescribing these agents to pregnant women with chronic HBV infection for

several years. ${ }^{71,72}$ However, pregnant infected women are more likely to visit the obstetrics clinic first, and may not seek consultation from hepatologists. The recent guideline from the

Chinese Society of Obstetrics and Gynecology recommends against antiviral treatment as

prophylaxis of perinatal transmission of $\mathrm{HBV} .{ }^{50}$ A survey of Chinese obstetricians showed that

only $11.7 \%$ agree with antiviral treatment during pregnancy. ${ }^{73}$ Delayed update of evidence and differences in research interest between obstetricians and hepatologists may contribute to the above knowledge and practices among gynaecology staff. The findings presented in this study

highlight the critical need to further summarize the clinical evidence and evaluate the costeffectiveness of antiviral treatment to prevent perinatal transmission of $\mathrm{HBV}$. by the RR of HBV transmission. However, LdT remains more cost-effective than LAM when transmission risk is reduced by $>8 \%$. The sensitivity analyses also indicate that more 
259

260

261

262

263

264

265

266

267

268

269

270

271

272

273

274

275

276

277

278

279

information is needed concerning the efficacy and cost of TDF. It is difficult to determine an added benefit of TDF when studies with large sample sizes show a $100 \%$ efficacy with LdT. ${ }^{32,44}$,

${ }^{45}$ As a result, the cost of TDF becomes the main variable affecting its cost-effectiveness. TDF is less expensive than LdT in Western countries such as Spain, ${ }^{74}$ where TDF would be considered more cost-effective assuming an equal efficacy to LdT. On this point, our results are consistent with the recent guidelines of the National Institute for Health and Care Excellence. ${ }^{70}$ TDF will also become cost-effective in China as its cost decreases.

There are several important strengths of the current study. This study is the first decision analysis that compares all currently available antiviral agents for the prevention of perinatal transmission of HBV. In the model used for the analyses, the only variables that differed among each antiviral strategy were the prevention efficacy and the cost. Consistent with previous studies, ${ }^{20-23}$ LAM was found to be cost-effective compared with the conventional IP, indicating that the findings concerning LdT and TDF are similarly valid and reliable. In addition, a systematic review was performed to summarize the prevention efficacy of each antiviral agent. Included in the current analyses are two newly published high-quality studies with large sample sizes. ${ }^{44,45}$ Finally, a network meta-analysis was used to evaluate the efficacies of each strategy, which combines direct and indirect comparisons and is superior to traditional pairwise analyses when there is an insufficient number of direct comparison studies. ${ }^{46}$

There are some limitations of this study that should be mentioned. First, the risk of side effects when using antiviral agents during pregnancy was not considered. However, controlled studies demonstrate that LAM, LdT, or TDF do not increase the number of birth defects or 
280 complications. ${ }^{12,16,26-45}$ Second, there is no consensus on when antiviral treatment should be

281 withdrawn, though most studies chose four weeks after delivery as the end time. Except for a 282 small fraction of mothers continuing to receive the treatment because of elevated ALT levels, 283 most mothers discontinued the treatment as planned with no associated severe adverse events, 284 though the results for mothers were not included in the current model. Third, there is no 285 consensus on the threshold of HBV-DNA level for initiating antiviral treatment in pregnant 286 women. Like most studies of relevant topic, the analysis used the threshold of $6 \log _{10} \operatorname{copies} / \mathrm{mL}$. 287 Lastly, the analysis focused only on pregnant women positive for HBeAg. Further studies 288 evaluating strategies to prevent perinatal transmission of $\mathrm{HBV}$ from $\mathrm{HBeAg-negative} \mathrm{mothers}$ 289 are needed..$^{75,76}$

290 In conclusion, this cost-effectiveness analysis focusing on pregnant women positive for 291 HBeAg with HBV-DNA $>6 \log _{10}$ copies/mL suggests that supplemental use of LdT during late 292 pregnancy combined with IP for their infants is cost-effective in China. 
294

295

296

297

298

299

300

301

302

303

304

305

306

307

308

309

310

311

312

313

314

315

316

\section{References}

1. Liang X, Bi S, Yang W, Wang L, Cui G, Cui F, Zhang Y, Liu J, Gong X, Chen Y, Wang F, Zheng H, Guo J, Jia Z, Ma J, Wang H, Luo H, Li L, Jin S, Hadler SC, Wang Y. Epidemiological serosurvey of hepatitis B in China-declining HBV prevalence due to hepatitis B vaccination. Vaccine 2009;27:6550-7.

2. World Health Organization. Disease and injury country estimates, 2004-2008. Available at: http://www.who.int/healthinfo/global_burden_disease/estimates_country_2004_2008/en. Accessed August 9, 2013. .

3. Chinese Center for Disease Control and Prevention. Prevention and treatment of viral hepatitis. Available at: http://www.chinacdc.cn/rdwd/201107/t20110726 49934.htm. Accessed 9 August, 2013.

4. Gambarin-Gelwan M. Hepatitis B in pregnancy. Clin Liver Dis 2007;11:945-63.

5. Patton H, Tran TT. Management of hepatitis B during pregnancy. Nat Rev Gastroenterol Hepatol 2014;11:402-9.

6. Stevens CE, Beasley RP, Tsui J, Lee WC. Vertical transmission of hepatitis B antigen in Taiwan. N Engl J Med $1975 ; 292: 771-4$.

7. Lee C, Gong Y, Brok J, Boxall EH, Gluud C. Hepatitis B immunisation for newborn infants of hepatitis B surface antigen-positive mothers. Cochrane Database Syst Rev 2006:CD004790.

8. Ni YH, Huang LM, Chang MH, Yen CJ, Lu CY, You SL, Kao JH, Lin YC, Chen HL, Hsu HY, Chen DS. Two decades of universal hepatitis $B$ vaccination in taiwan: impact and implication for future strategies. Gastroenterology 2007;132:1287-93.

9. Burgis J, Kong D, Salibay C, Zipprich J, Harriman K, So S. Risk factors associated with immunoprophylaxis failure in infants born to mothers with chronic hepatitis $b$ infection in california. Gastroenterology 2014;146:S-762.

10. Burk RD, Hwang LY, Ho GY, Shafritz DA, Beasley RP. Outcome of perinatal hepatitis B virus exposure is dependent on maternal virus load. J Infect Dis 1994;170:1418-23.

11. del Canho R, Grosheide PM, Schalm SW, de Vries RR, Heijtink RA. Failure of neonatal hepatitis B vaccination: the role of HBV-DNA levels in hepatitis B carrier mothers and HLA antigens in neonates. J Hepatol 1994;20:483-6.

12. Brown RS, Jr., Verna EC, Pereira MR, Tilson HH, Aguilar C, Leu CS, Buti M, Fagan EA. Hepatitis B virus and human immunodeficiency virus drugs in pregnancy: findings from the Antiretroviral Pregnancy Registry. J Hepatol 2012;57:953-9.

13. Fontana RJ. Side effects of long-term oral antiviral therapy for hepatitis B. Hepatology 2009;49:S185-95.

14. Wang L, Kourtis AP, Ellington S, Legardy-Williams J, Bulterys M. Safety of tenofovir during pregnancy for the mother and fetus: a systematic review. Clin Infect Dis 2013;57:1773-81.

15. Yi W, Liu M, Cai HD. Safety of lamivudine treatment for chronic hepatitis B in early pregnancy. World J Gastroenterol 2012;18:6645-50.

16. Celen MK, Mert D, Ay M, Dal T, Kaya S, Yildirim N, Gulsun S, Barcin T, Kalkanli S, Dal MS, Ayaz C. Efficacy and safety of tenofovir disoproxil fumarate in pregnancy for the prevention of vertical transmission of HBV infection. World J Gastroenterol 2013;19:9377-82.

17. Han L, Zhang HW, Xie JX, Zhang Q, Wang HY, Cao GW. A meta-analysis of lamivudine for interruption of mother-to-child transmission of hepatitis B virus. World J Gastroenterol 2011;17:4321-33. 
334

18. Lu YP, Liang XJ, Xiao XM, Huang SM, Liu ZW, Li J, Hocher B, Chen YP. Telbivudine during the second and third trimester of pregnancy interrupts HBV intrauterine transmission: a systematic review and metaanalysis. Clin Lab 2014;60:571-86.

19. Pan CQ, Mi L, Bunchorntavakul C, Karsdon J, Huang WM, Singhvi G, Ghany MG, Reddy KR. Tenofovir disoproxil fumarate for prevention of vertical transmission of hepatitis $B$ virus infection by highly viremic pregnant women: a case series. Dig Dis Sci 2012;57:2423-9.

20. Fan L, Owusu-Edusei K, Jr., Schillie SF, Murphy TV. Cost-effectiveness of testing hepatitis B-positive pregnant women for hepatitis B e antigen or viral load. Obstet Gynecol 2014;123:929-37.

21. Hung $\mathrm{HF}$, Chen $\mathrm{HH}$. Cost-effectiveness analysis of prophylactic lamivudine use in preventing vertical transmission of hepatitis B virus infection. PharmacoEconomics 2011;29:1063-73.

22. Nayeri UA, Werner EF, Han CS, Pettker CM, Funai EF, Thung SF. Antenatal lamivudine to reduce perinatal hepatitis B transmission: a cost-effectiveness analysis. Am J Obstet Gynecol 2012;207:231 e1-7.

23. Unal ER, Lazenby GB, Lintzenich AE, Simpson KN, Newman R, Goetzl L. Cost-effectiveness of maternal treatment to prevent perinatal hepatitis B virus transmission. Obstet Gynecol 2011;118:655-62.

24. Hutton DW, So SK, Brandeau ML. Cost-effectiveness of nationwide hepatitis B catch-up vaccination among children and adolescents in China. Hepatology 2010;51:405-14.

25. National Health and Family Planning Commission of the People's Republic of China. China Public Health Statistical Yearbook 2011. Available at: http://www.moh.gov.cn/zhuzhan/index.shtml. Accessed 9 August, 2013.

26. Feng HF, Zhang SF. Effect on interruption of hepatitis B virus vertical transmission by lamivudine. Shi Yong Er Ke Lin Chuang Za Zhi 2007;22:1019-20.

27. Guo YZ, Li SX, Ge SL, Wang JH. The clinical application of lamivudine in interdiction of maternal-to-child transmission for HBsAg, HBeAg-positive pregnant women. Lin Chuang He Li Yong Yao 2008;1:8-9.

28. Xu WM, Cui YT, Wang L, Yang H, Liang ZQ, Li XM, Zhang SL, Qiao FY, Campbell F, Chang CN, Gardner S, Atkins M. Lamivudine in late pregnancy to prevent perinatal transmission of hepatitis B virus infection: a multicentre, randomized, double-blind, placebo-controlled study. J Viral Hepat 2009;16:94-103.

29. Zhang YF. The effect of lamivudine on interruption of mother-to-child transmission in 50 pregnant women with chronic HBV infection. Shi Yong Fu Chan Ke Za Zhi 2010;26:367-8.

30. Zhao BD, Liao XQ, Peng GJ, Liu J, Lin CH. The efficacy of telbivudine combined with HBV vaccine and HBIG in interrupting mother-to-child transmission of HBV in 60 cases. Zhong Guo Xian Dai Yao Wu Ying Yong 2010;4:37-8.

31. Guo HJ, Zhang Y. The efficacy of telbivudine in interrupting mother-to-child HBV transmission in pregnant women with high levels of viremia. Chang Zhi Yi Xue Yuan Xue Bao 2011;25:368-70.

32. Han GR, Cao MK, Zhao W, Jiang HX, Wang CM, Bai SF, Yue X, Wang GJ, Tang X, Fang ZX. A prospective and open-label study for the efficacy and safety of telbivudine in pregnancy for the prevention of perinatal transmission of hepatitis B virus infection. J Hepatol 2011;55:1215-21.

33. Yao ZC, Chen MC, Liao WY, Zhang YP, Wu Y, Li LY, Feng J, Lin MS, Chen CA, Zheng DG, Zhuang JQ. The efficacy and safety of telbivudine in blocking intrauterine hepatitis B viral transmission. Shi Yong Gan Zang Bing Za Zhi 2011;14:259-61.

34. Zhou YJ, Zheng JL, Pan HJ, Jiang S. Efficacy and safety of telbivudine in pregnant chronic hepatitis B patients. Zhong Hua Gan Zang Bing Za Zhi 2011;19:861-2. 
375 35. Pan CQ, Han GR, Jiang HX, Zhao W, Cao MK, Wang CM, Yue X, Wang GJ. Telbivudine prevents vertical transmission from HBeAg-positive women with chronic hepatitis B. Clin Gastroenterol Hepatol 2012;10:520-6.

36. Peng BA, Zhao Y, Yang XF, Liao MF, Xu LH, Yu YH. The efficacy and safety of telbivudine in blocking mother-to-child transmission of hepatitis B virus. Zhong Guo Yao Xue Za Zhi 2012;47:855-7.

37. Wang EJ. Comparision of effecacy and safety between lamivudine and telbivudine in blocking vertical transmission of hepatitis B virus in late stage pregnancy. Quan Ke Yi Shi Za Zhi 2012;15:3628-30.

38. Wang WP, Zhao J. The study of efficacy and side effects of telbivudine for treatment of patients with chronic hepatitis B in pregnant women. Xian Dai Fu Chan Ke Jin Zhan 2012;21:697-9.

39. Bai HL, Shang HL, Li ZL. The clinical study of telbivudine in blocking intrauterine transmission of hepatitis B virus during late pregnancy. Zhong Guo Yi Xue Gong Cheng 2013;21:53-4.

40. Jiang HN, Fan LY, Li DZ, Wan J, Ye JJ. Clinical trial of telbivudine in the treatment of chronic hepatitis B in patients during the third trimester of pregnancy. Lin Chuang Gan Dan Bing Za Zhi 2013;29:101-3.

41. Sun WH, Chu LL, Liu WL, Hao AH, Ma L, Wan Q, Ren R, Xin YN. Efficacy and safety of telbivudine in preventing mother-to-infant transmission of HBV in pregnant women in high HBV DNA load. Lin Chuang Gan Dan Bing Za Zhi 2013;29:596-9.

42. Wu QX, Deng GH, Li JN, Li L, Sun XW, Pan MM, Huang HF, He DM, Yan ZH, Xu C, Li MS, Tang W, Liu MD, Wang YM. Effects of telbivudine on transmission of HBsAg and HBeAg throught placenta in HBV infected pregnant women in second or third trimester. Di San Jun Yi Da Xue Xue Bao 2013;35:665-8.

43. Zeng YM, Chen R, Lou GQ, Shi JP. Study of the strategy about cessation of lamivudine used in HBV intrauterine infection. Yi Xue Yan Jiu Za Zhi 2013;42:87-90.

44. Yu MM, Jiang Q, Ji Y, Wu KH, Ju LL, Tang X, Yang YF. Comparison of telbivudine versus lamivudine in interrupting perinatal transmission of hepatitis B virus. J Clin Virol 2014;61:55-60.

45. Zhang $\mathrm{H}$, Pan $\mathrm{CQ}$, Pang $\mathrm{Q}$, Tian R, Yan M, Liu X. Telbivudine or lamivudine use in late pregnancy safely reduces perinatal transmission of hepatitis $B$ virus in real-life practice. Hepatology 2014;60:468-75.

46. Caldwell DM, Ades AE, Higgins JP. Simultaneous comparison of multiple treatments: combining direct and indirect evidence. BMJ 2005;331:897-900.

47. Lai CL, Gane E, Liaw YF, Hsu CW, Thongsawat S, Wang Y, Chen Y, Heathcote EJ, Rasenack J, Bzowej N, Naoumov NV, Di Bisceglie AM, Zeuzem S, Moon YM, Goodman Z, Chao G, Constance BF, Brown NA. Telbivudine versus lamivudine in patients with chronic hepatitis B. N Engl J Med 2007;357:2576-88.

48. Marcellin P, Heathcote EJ, Buti M, Gane E, de Man RA, Krastev Z, Germanidis G, Lee SS, Flisiak R, Kaita K, Manns M, Kotzev I, Tchernev K, Buggisch P, Weilert F, Kurdas OO, Shiffman ML, Trinh H, Washington MK, Sorbel J, Anderson J, Snow-Lampart A, Mondou E, Quinn J, Rousseau F. Tenofovir disoproxil fumarate versus adefovir dipivoxil for chronic hepatitis B. N Engl J Med 2008;359:2442-55.

49. Chinese Society of Hepatology and Chinese Society of Infectious Diseases. The guideline of prevention and treatment for chronic hepatitis B (2010 version). Zhonghua Gan Zang Bing Za Zhi 2011;19:13-24.

50. Chinese Society of Gynaecology and Obstetrics. The clinical guideline of prevention for mother-to-child transmission of hepatitis B virus. Zhong Hua Fu Chan Ke Za Zhi 2013;48:151-4.

414 Liang X, Yang W. Evaluation of policies and practices to prevent mother to child transmission of hepatitis B virus in China: results from China GAVI project final evaluation. Vaccine 2013;31 Suppl 9:J36-42. 
416 52. Guo Y, Liu J, Meng L, Meina H, Du Y. Survey of HBsAg-positive pregnant women and their infants regarding

417 measures to prevent maternal-infantile transmission. BMC Infect Dis 2010;10:26.

53. Hu Y, Zhang S, Luo C, Liu $Q$, Zhou YH. Gaps in the prevention of perinatal transmission of hepatitis $B$ virus between recommendations and routine practices in a highly endemic region: a provincial populationbased study in China. BMC Infect Dis 2012;12:221.

54. Ayres A, Yuen L, Jackson KM, Manoharan S, Glass A, Maley M, Yoo W, Hong SP, Kim SO, Luciani F, Bowden DS, Bayliss J, Levy MT, Locarnini SA. Short duration of lamivudine for the prevention of hepatitis B virus transmission in pregnancy: Lack of potency and selection of resistance mutations. J Viral Hepat 2014;21:809-17.

55. Ho A, Tran TT. Pregnant women and their willingness to be treated for hepatitis B during pregnancy. Gastroenterology 2011;140:S930.

56. National Bureau of Statistics of China. Available at: http://www.stats.gov.cn/tjsj/pcsj/rkpc/6rp/indexch.htm. Accessed 9 August, 2013.

57. Fung J, Seto WK, Lai CL, Yuen J, Wong DK, Yuen MF. Profiles of HBV DNA in a large population of Chinese patients with chronic hepatitis B: implications for antiviral therapy. J Hepatol 2011;54:195-200.

58. Guo Y, Zhang W, Zhang Y, Lin X, Zhang B, Chen C, Du Y. Cost-effectiveness analysis of preventing motherto-child transmission of hepatitis B by injecting hepatitis B immune globulin. Eur J Gastroenterol Hepatol 2012;24:1363-9.

59. Shi G, Zhang SX. Decision tree and cost-benefit analysis on strategies related to preventing maternalinfantile transmission of hepatitis B virus infection. Zhonghua Liu Xing Bing Xue Za Zhi 2013;34:273-8.

60. Price Bureau of Shaanxi Province. Available at: www.sx111.com. Accessed 9 August, 2013.

61. Kangdele Pharmacy. Available at: http://www.baiji.com.cn. Accessed 16 October, 2014.

62. Chen $D$, Yao GB, Chen W. Economic evaluation of peginterferon afa-2a and lamivudine in the treatment of HBeAg-positive chronic hepatitis B. Chin J Infect Dis 2007;25:468-472.

63. Hu M, Chen W. Assessment of total economic burden of chronic hepatitis B (CHB)-related diseases in Beijing and Guangzhou, China. Value Health 2009;12 Suppl 3:S89-92.

64. National Bureau of Statistics of China. Available at: www.stats.gov.cn. Accessed 9 August, 2013.

65. World Health Organization. Available at: http://www.who.int/choice/costs/en/ Accessed 16 October, 2014.

66. Geisler BP. Automating First- and Second-order Monte Carlo Simulations for Markov Models in TreeAge Pro. In: Mordechai S, eds. Applications of Monte Carlo Method in Science and Engineering. Shanghai: InTech, 2011:917-930.

67. Kanwal F, Gralnek IM, Martin P, Dulai GS, Farid M, Spiegel BM. Treatment alternatives for chronic hepatitis B virus infection: a cost-effectiveness analysis. Ann Intern Med 2005;142:821-31.

68. European Association For The Study Of The Liver. EASL clinical practice guidelines: Management of chronic hepatitis B virus infection. J Hepatol 2012;57:167-85.

69. Liaw YF, Kao JH, Piratvisuth T, Chan HLY, Chien RN, Liu CJ, Gane E, Locarnini S, Lim SG, Han KH, Amarapurkar D, Cooksley G, Jafri W, Mohamed R, Hou JL, Chuang WL, Lesmana LA, Sollano JD, Suh DJ, Omata M. Asian-Pacific consensus statement on the management of chronic hepatitis B: a 2012 update. Hepatol Int 2012;6:531-61.

70. Sarri G, Westby M, Bermingham S, Hill-Cawthorne G, Thomas H. Diagnosis and management of chronic 
457

458

459

460

461

462

463

464

465

466

467

468

469

470

471

472

473

hepatitis B in children, young people, and adults: summary of NICE guidance. BMJ 2013;346:f3893.

71. Li XM, Yang YB, Hou HY, Shi ZJ, Shen HM, Teng BQ, Li AM, Shi MF, Zou L. Interruption of HBV intrauterine transmission: a clinical study. World J Gastroenterol 2003;9:1501-3.

72. Zhang LJ, Wang L. Blocking intrauterine infection by telbivudine in pregnant chronic hepatitis B patients. Zhonghua Gan Zang Bing Za Zhi 2009;17:561-3.

73. Hu Y, Dai X, Zhou YH, Yang H. A knowledge survey of obstetrics and gynecology staff on the prevention of mother-to-child transmission of hepatitis B virus. J Infect Dev Ctries 2013;7:391-7.

74. Buti M, Brosa M, Casado MA, Rueda M, Esteban R. Modeling the cost-effectiveness of different oral antiviral therapies in patients with chronic hepatitis B. J Hepatol 2009;51:640-6.

75. Kubo A, Shlager L, Marks AR, Lakritz D, Beaumont C, Gabellini K, Corley DA. Prevention of vertical transmission of hepatitis B: an observational study. Ann Intern Med 2014;160:828-35.

76. Pan CQ, Duan ZP, Bhamidimarri KR, Zou HB, Liang XF, Li J, Tong MJ. An algorithm for risk assessment and intervention of mother to child transmission of hepatitis B virus. Clin Gastroenterol Hepatol 2012;10:4529. 


\section{Figure Legends}

475 Fig. 1. Decision tree model showing the four strategies for preventing perinatal hepatitis B

476 transmission. HBIG: hepatitis B immunoglobulin; IP: immunoprophylaxis; LAM: lamivudine;

477 LdT: telbivudine; TDF: tenofovir. 


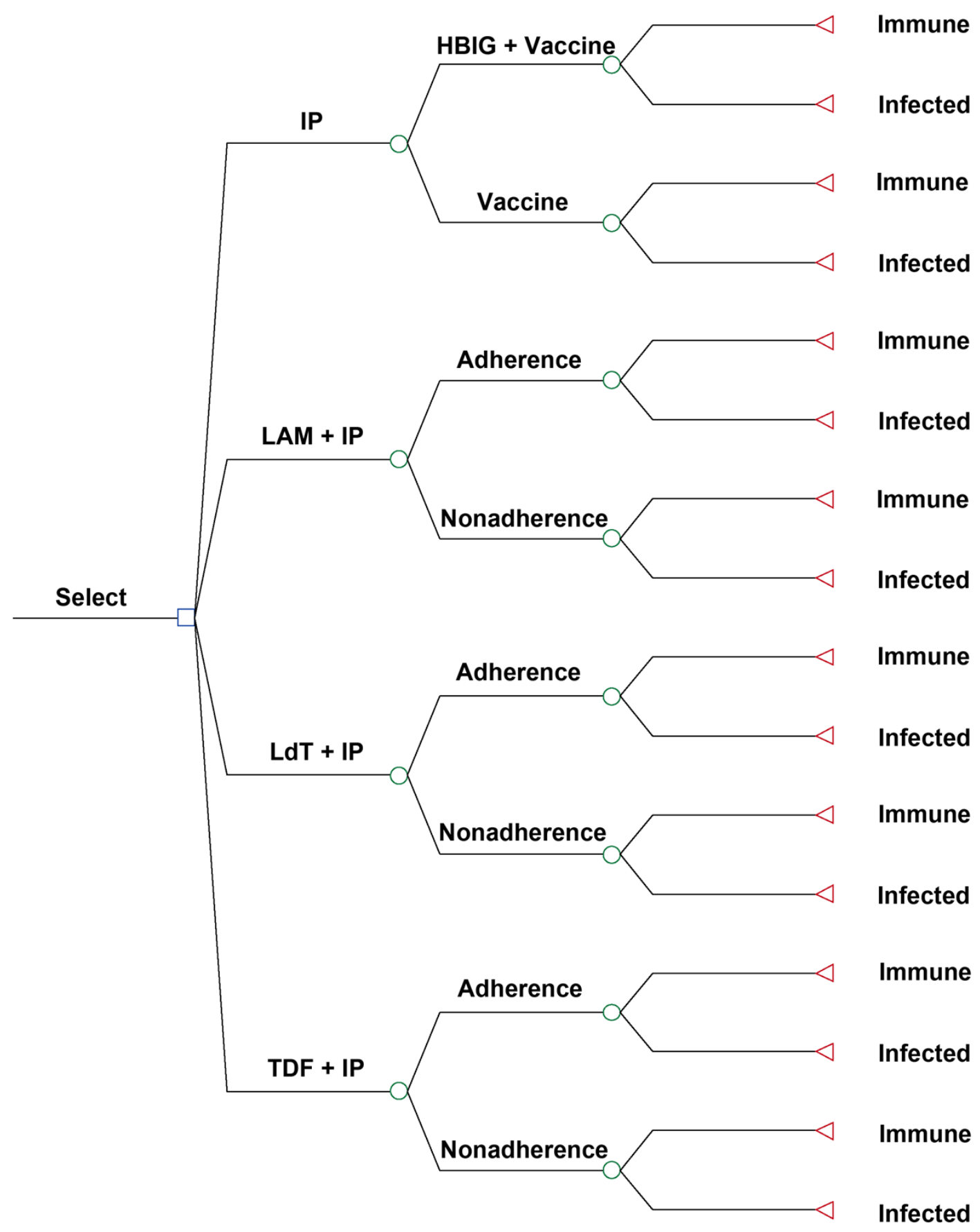

Fig. 2. Effect of antiviral strategies on reducing perinatal hepatitis B transmission. The area of each rectangle represents the proportion of pregnant women, and the density of dots represents 
482 the probability of perinatal transmission of HBV. The unit of HBV-DNA is copies/mL. HBeAg:

483 hepatitis B e antigen; HBV: hepatitis B virus; IP: immunoprophylaxis; LAM: lamivudine; LdT:

484 telbivudine; TDF: tenofovir.

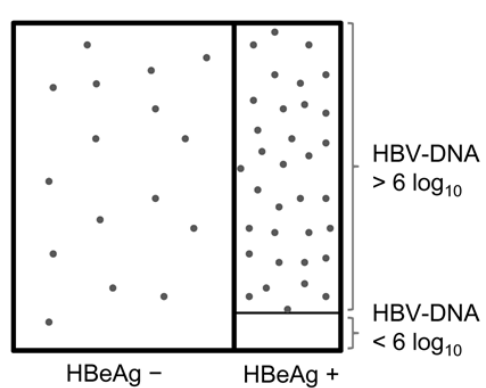

IP
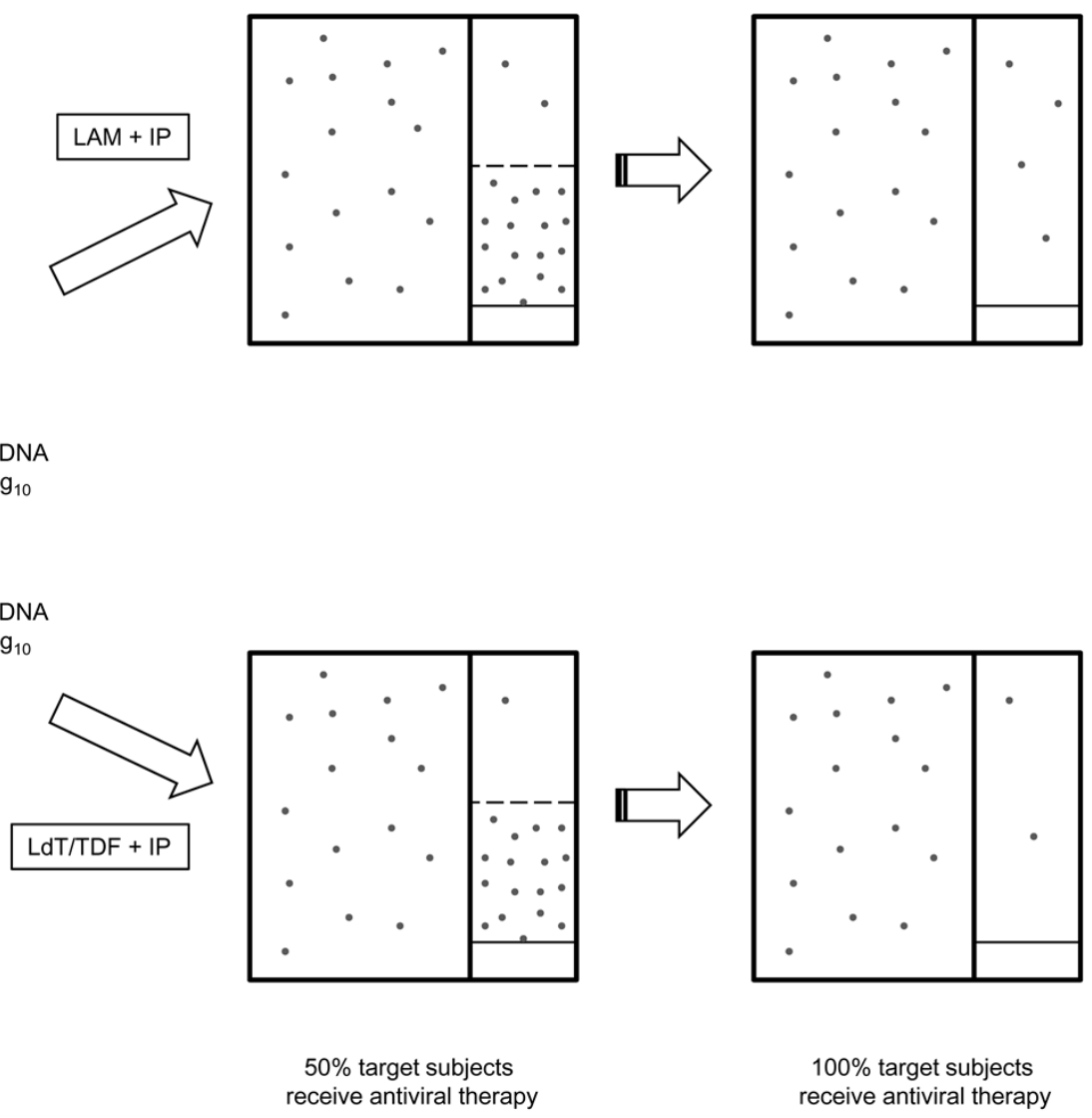

$100 \%$ target subjects receive antiviral therapy 
transmission. Chinese gross domestic product per capita was approximately $\$ 6,800$ in 2013 . IP:

494 immunoprophylaxis; LAM: lamivudine; LdT: telbivudine; TDF: tenofovir; USD: US Dollar;

495 QALY; quality-adjusted life year.

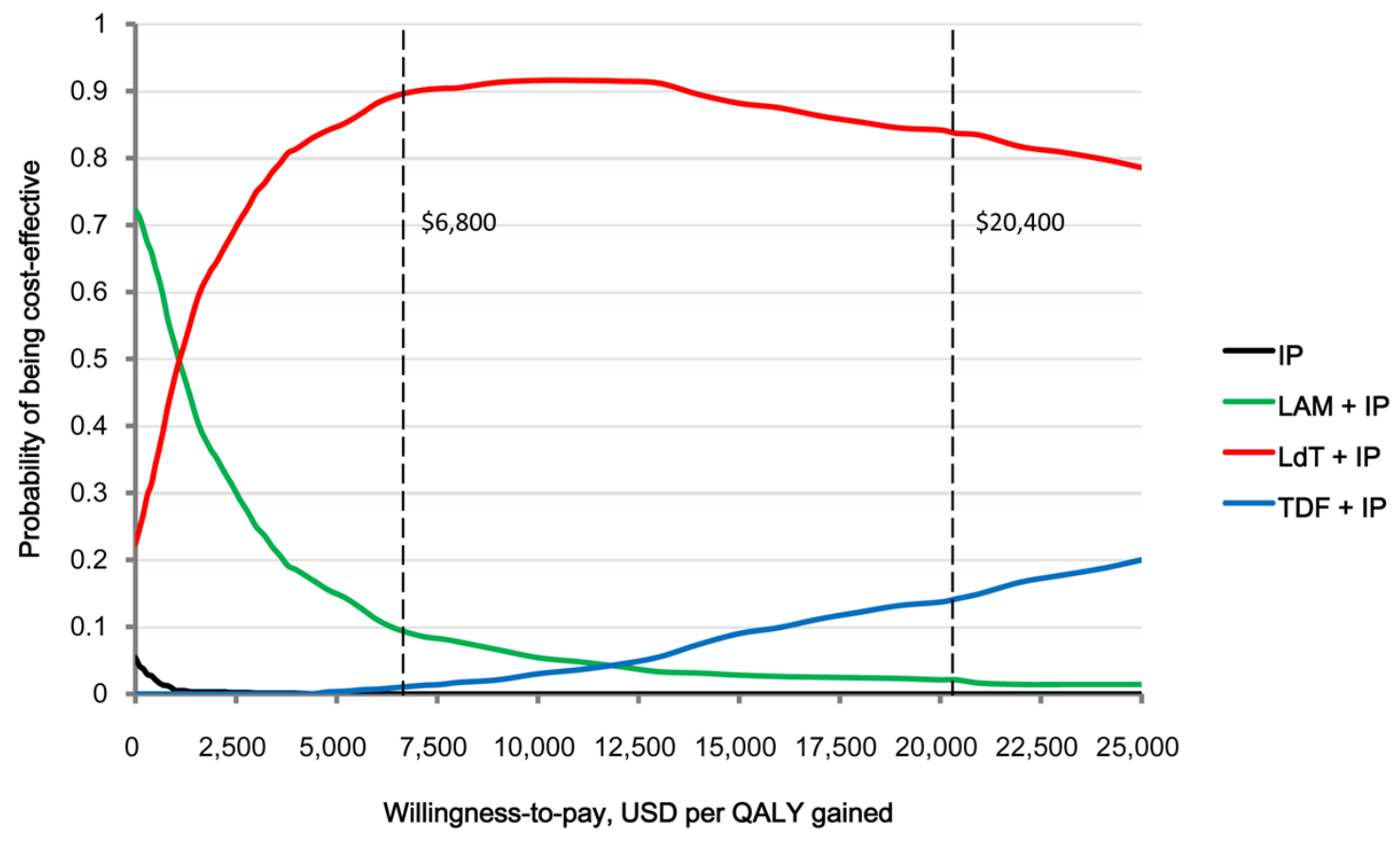

496

497 
498 Table 1. Clinical variables for base-case and sensitivity analysis

\begin{tabular}{|c|c|c|c|}
\hline Variable & Base case & Range & Ref. \\
\hline $\begin{array}{l}\text { Probability of perinatal hepatitis B transmission } \\
\text { with IP }\end{array}$ & $11.7 \%$ & $2.8-42.3 \%$ & $16,26-45$ \\
\hline \multicolumn{4}{|l|}{ Relative risk of perinatal hepatitis B transmission } \\
\hline Vaccination vs. IP & 1.85 & $1.37-2.44$ & 7 \\
\hline LAM + IP vs. IP & 0.23 & $0.13-0.41$ & $26-45$ \\
\hline LdT + IP vs. LAM + IP & 0.56 & $0.25-1^{\dagger}$ & $26-45$ \\
\hline $\mathrm{TDF}+\mathrm{IP}$ vs. $\mathrm{LdT}+\mathrm{IP}$ & 1 & $0.5-1$ & $\begin{array}{l}16,19,47, \\
48\end{array}$ \\
\hline Compliance rate of IP & $44.0 \%$ & $37.6-86.0 \%$ & $51-53$ \\
\hline $\begin{array}{l}\text { Adherence to antiviral treatment during } \\
\text { pregnancy }\end{array}$ & $98.4 \%$ & $80.0-100 \%$ & $26-45$ \\
\hline \multicolumn{4}{|l|}{ Natural history parameters } \\
\hline Normal ALT to elevated ALT & $0.2 \%$ & $0.1-0.2 \%$ & 24 \\
\hline Normal ALT to HCC & $0.3 \%$ & $0.2-0.5 \%$ & 24 \\
\hline $\begin{array}{l}\text { Chronic HBV with elevated ALT to } \\
\text { compensated cirrhosis }\end{array}$ & $3.8 \%$ & $0.5-12.3 \%$ & 24 \\
\hline Chronic HBV with elevated ALT to HCC & $1.5 \%$ & $0.5-9.5 \%$ & 24 \\
\hline $\begin{array}{l}\text { Durable virologic response while on } \\
\text { treatment }\end{array}$ & $15.0 \%$ & $5.0-30.0 \%$ & 24 \\
\hline Receiving treatment with durable response & $50.0 \%$ & $0.0-100 \%$ & 24 \\
\hline Durable response relapse to elevated ALT & $7.0 \%$ & $2.0-15.0 \%$ & 24 \\
\hline Durable response relapse to $\mathrm{HCC}$ & $0.3 \%$ & $0.2-0.5 \%$ & 24 \\
\hline Compensated to decompensated cirrhosis & $7.0 \%$ & $3.0-10.0 \%$ & 24 \\
\hline Mortality from compensated cirrhosis & $4.8 \%$ & $2.0-13.1 \%$ & 24 \\
\hline Mortality from decompensated cirrhosis & $17.3 \%$ & $5.8-22.1 \%$ & 24 \\
\hline Cirrhosis to HCC & $3.3 \%$ & $1.0-11.3 \%$ & 24 \\
\hline $\begin{array}{l}\text { Liver transplantation for decompensated } \\
\text { cirrhosis }\end{array}$ & $1.5 \%$ & $0.0-40.0 \%$ & 24 \\
\hline Mortality from $\mathrm{HCC}$ & $40.0 \%$ & $32.0-47.3 \%$ & 24 \\
\hline Liver transplantation for $\mathrm{HCC}$ & $0.1 \%$ & $0.0-40.0 \%$ & 24 \\
\hline Mortality first year after liver transplantation & $15.0 \%$ & $7.5-30.0 \%$ & 24 \\
\hline $\begin{array}{l}\text { Mortality second and subsequent years after } \\
\text { liver transplantation }\end{array}$ & $1.5 \%$ & $0.8-3.0 \%$ & 24 \\
\hline \multicolumn{4}{|c|}{ Health-state utility weights for quality of life adjustments } \\
\hline Normal ALT & 1.00 & $0.95-1.00$ & 24 \\
\hline Elevated ALT & 0.99 & $0.90-1.00$ & 24 \\
\hline Durable response & 1.00 & $0.90-1.00$ & 24 \\
\hline
\end{tabular}




\begin{tabular}{llll}
\hline Variable & Base case & Range & Ref. \\
\hline Compensated cirrhosis & 0.80 & $0.70-0.93$ & 24 \\
Decompensated cirrhosis & 0.60 & $0.50-0.70$ & 24 \\
HCC & 0.73 & $0.50-0.80$ & 24 \\
Liver transplantation & 0.86 & $0.70-0.90$ & 24 \\
\hline
\end{tabular}

499 ALT: alanine aminotransferase; HBV: hepatitis B virus; HCC: hepatocellular carcinoma; IP:

500 immunoprophylaxis; LAM: lamivudine; LdT: telbivudine; TDF: tenofovir.

501 †revention efficacy of LAM was assumed to not be superior to LdT. 
502 Table 2. Cost variables for base-case and sensitivity analysis

\begin{tabular}{|c|c|c|c|}
\hline Variable & $\begin{array}{l}\text { Base case } \\
\text { (USD) }\end{array}$ & $\begin{array}{l}\text { Range } \\
\text { (USD) }\end{array}$ & Ref. \\
\hline Hepatitis B vaccination, three times & $\$ 3.0$ & $\$ 1.5-6.0$ & 59 \\
\hline Hepatitis B immunoglobulin administration & $\$ 40.0$ & $\$ 20.0-80.0$ & 58,59 \\
\hline LAM, daily ${ }^{\dagger}$ & $\$ 2.5$ & $\$ 1.3-5.0$ & 60 \\
\hline $\mathrm{LdT}$, daily ${ }^{\dagger}$ & $\$ 3.6$ & $\$ 1.8-7.2$ & 60 \\
\hline TDF, daily ${ }^{\dagger}$ & $\$ 8.7$ & $\$ 4.4-17.4$ & 61 \\
\hline $\begin{array}{l}\text { Ratio of proportion of mothers with }<6 \text { to }>6 \\
\log _{10} \text { copies } / \mathrm{mL} \mathrm{HBV-DNA}\end{array}$ & 0.136 & $0.068-0.273$ & 57 \\
\hline HBV-DNA quantification & $\$ 16.3$ & $\$ 8.2-32.6$ & 60 \\
\hline HBV-marker test & $\$ 3.3$ & $\$ 1.6-6.6$ & 60 \\
\hline Chronic hepatitis B, annual $^{\#}$ & $\$ 1,780$ & $\$ 890-3,560$ & 63 \\
\hline Compensated cirrhosis, annual & $\$ 2,759$ & $\$ 1,380-5,518$ & 63 \\
\hline Decompensated cirrhosis, annual & $\$ 5,130$ & $\$ 2,565-10,260$ & 63 \\
\hline Hepatocellular carcinoma, annual & $\$ 7,302$ & $\$ 3,651-14,604$ & 63 \\
\hline Liver transplantation, first year & $\$ 37,458$ & $\$ 18,729-74,916$ & 62 \\
\hline $\begin{array}{l}\text { Liver transplantation, second and subsequent } \\
\text { years, annual }\end{array}$ & $\$ 3,276$ & $\$ 1,638-6,552$ & 62 \\
\hline Discount rate, annual & $3 \%$ & $0-5 \%$ & - \\
\hline
\end{tabular}

HBV: hepatitis B virus; LAM: lamivudine; LdT: telbivudine; TDF: tenofovir; USD: US Dollar.

${ }^{\dagger}$ Administered from week 28 of gestation to 4 weeks after delivery.

$\# 50 \%$ of patients with durable response were assumed to continue receiving treatment. 
508 Table 3. Short-term outcomes

\begin{tabular}{llllll}
\hline Strategy & $\begin{array}{l}\text { Infections } \\
(\boldsymbol{n})\end{array}$ & $\begin{array}{l}\text { Incremental } \\
\text { infections averted } \\
(\boldsymbol{n})\end{array}$ & $\begin{array}{l}\text { Cost } \\
\text { (USD) }\end{array}$ & $\begin{array}{l}\text { Incremental cost } \\
\text { (USD) }\end{array}$ & ICER \\
\hline IP & 1,727 & - & $\$ 239,000$ & - & - \\
LAM + IP & 284 & 1,443 & $\$ 3,078,568$ & $\$ 2,839,568$ & 1,967 \\
LdT + IP & 167 & 117 & $\$ 4,147,944$ & $\$ 1,069,376$ & 9,178 \\
TDF + IP & 167 & 0 & $\$ 9,105,960$ & $\$ 4,958,016$ & - \\
\hline
\end{tabular}

ICER: incremental cost-effectiveness ratio (US dollars per incremental infection averted); IP: immunoprophylaxis;

510 LAM: lamivudine; LdT: telbivudine; TDF: tenofovir; USD; US Dollar. 
512 Table 4. Long-term outcomes

\begin{tabular}{lccccccc}
\hline Strategy & $\begin{array}{c}\text { HCC } \\
(\boldsymbol{n})\end{array}$ & $\begin{array}{c}\text { HBV- } \\
\text { related } \\
\text { deaths } \\
(\boldsymbol{n})\end{array}$ & $\begin{array}{c}\text { QALY } \\
\text { s }\end{array}$ & $\begin{array}{c}\text { Incrementa } \\
\text { I QALYs }\end{array}$ & $\begin{array}{c}\text { Cost } \\
\text { (USD) }\end{array}$ & $\begin{array}{c}\text { Incremental } \\
\text { cost } \\
\text { (USD) }\end{array}$ & $\begin{array}{c}\text { ICER } \\
(\mathbf{9 5 \%} \text { CI) }\end{array}$ \\
\hline IP & 385 & 304 & 292,167 & - & $\$ 4,897,077$ & - & Dominated \\
TDF+IP & 37 & 29 & 295,664 & - & $\$ 9,556,428$ & - & Dominated \\
LAM+IP & 63 & 50 & 295,403 & - & $\$ 3,843,301$ & - & - \\
LdT+IP & 37 & 29 & 295,664 & 261 & $\$ 4,598,412$ & $\$ 755,111$ & $\$ 2,891$ \\
& & & & & & & $(-\$ 932 \sim \$ 20,372)$ \\
\hline
\end{tabular}

513 CI: confidence interval; HBV: hepatitis B virus; HCC: hepatocellular carcinoma; ICER: incremental cost-

514 effectiveness ratio (US Dollar per quality-adjusted life year gained); IP: immunoprophylaxis; LAM: lamivudine;

515 LdT: telbivudine; QALY: quality-adjusted life year; TDF: tenofovir; USD; US Dollar.

516 
1

Decision tree model showing the four strategies for preventing perinatal hepatitis B transmission.

HBIG: hepatitis B immunoglobulin; IP: immunoprophylaxis; LAM: lamivudine; LdT: telbivudine; TDF: tenofovir. 


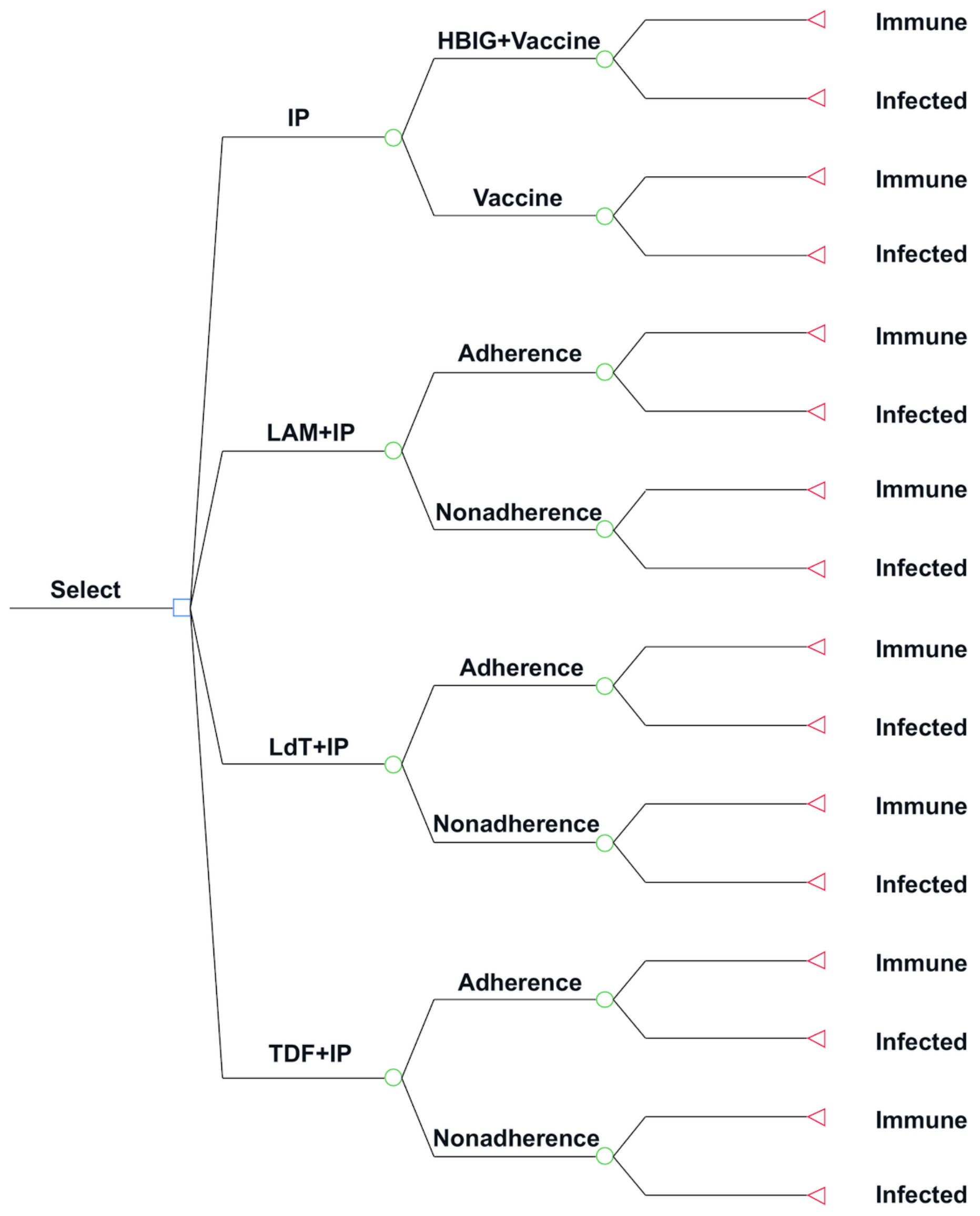


2

Effect of antiviral strategies on reducing perinatal hepatitis B transmission.

The area of each rectangle represents the proportion of pregnant women, and the density of dots represents the probability of perinatal transmission of HBV. The unit of HBV-DNA is copies/mL. HBeAg: hepatitis B e antigen; HBV: hepatitis B virus; IP: immunoprophylaxis; LAM: lamivudine; LdT: telbivudine; TDF: tenofovir.

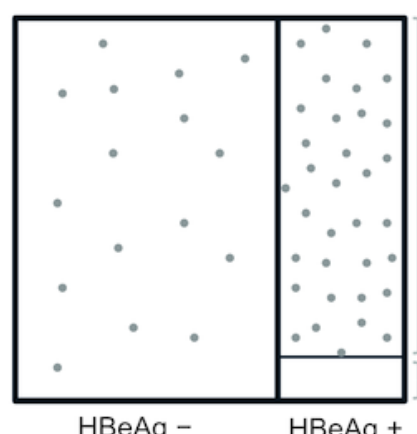

IP

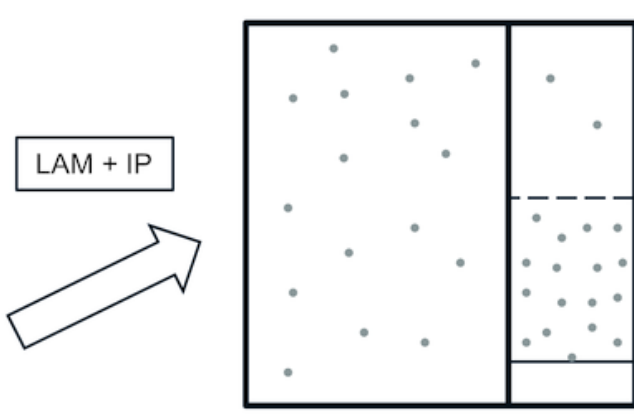

HBV-DNA

$>6 \log _{10}$

HBV-DNA

$<6 \log _{10}$

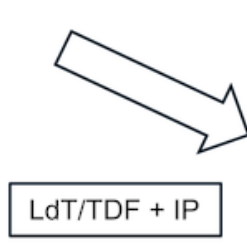

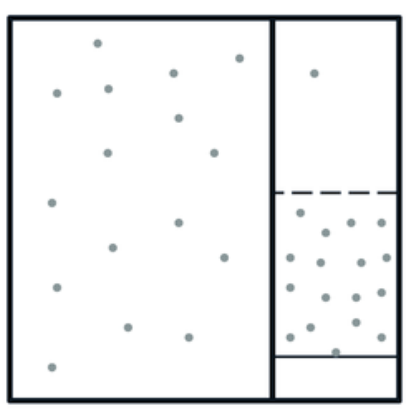

$50 \%$ target subjects receive antiviral therapy
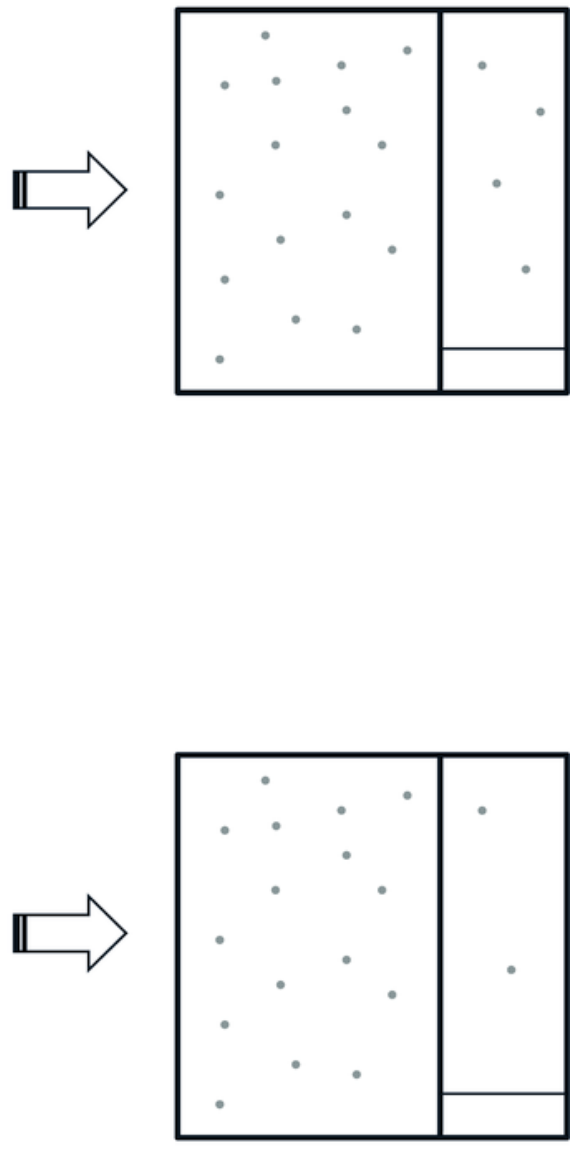

$100 \%$ target subjects receive antiviral therapy 
3

Acceptability curves of the four strategies for preventing perinatal hepatitis B transmission.

Chinese gross domestic product per capita was approximately $\$ 6,800$ in 2013. IP: immunoprophylaxis; LAM: lamivudine; LdT: telbivudine; TDF: tenofovir; USD: US Dollar; QALY; quality-adjusted life year.

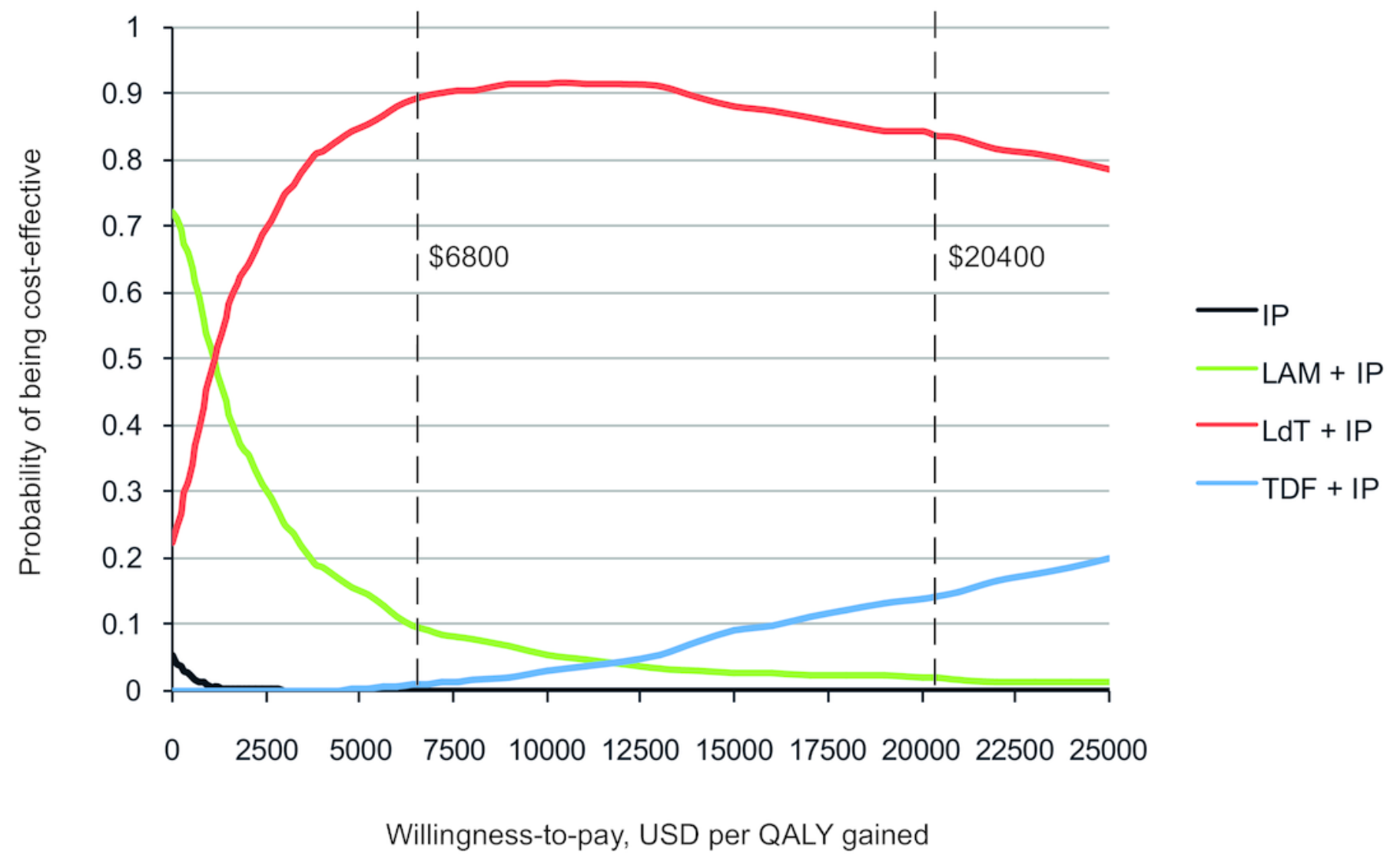




\section{Table 1 (on next page)}

Clinical variables for base-case and sensitivity analysis 


\begin{tabular}{|c|c|c|c|}
\hline Variable & Base case & Range & Ref. \\
\hline $\begin{array}{l}\text { Probability of perinatal hepatitis B transmission } \\
\text { with IP }\end{array}$ & $11.7 \%$ & $2.8-42.3 \%$ & $16,26-45$ \\
\hline \multicolumn{4}{|l|}{ Relative risk of perinatal hepatitis B transmission } \\
\hline Vaccination vs. IP & 1.85 & $1.37-2.44$ & 7 \\
\hline LAM + IP vs. IP & 0.23 & $0.13-0.41$ & $26-45$ \\
\hline $\mathrm{LdT}+\mathrm{IP} \boldsymbol{v} \boldsymbol{s} . \mathrm{LAM}+\mathrm{IP}$ & 0.56 & $0.25-1^{\dagger}$ & $26-45$ \\
\hline TDF + IP vs. LdT + IP & 1 & $0.5-1$ & $\begin{array}{l}16,19,47 \\
48\end{array}$ \\
\hline Compliance rate of IP & $44.0 \%$ & $37.6-86.0 \%$ & $51-53$ \\
\hline $\begin{array}{l}\text { Adherence to antiviral treatment during } \\
\text { pregnancy }\end{array}$ & $98.4 \%$ & $80.0-100 \%$ & $26-45$ \\
\hline \multicolumn{4}{|l|}{ Natural history parameters } \\
\hline Normal ALT to elevated ALT & $0.2 \%$ & $0.1-0.2 \%$ & 24 \\
\hline Normal ALT to HCC & $0.3 \%$ & $0.2-0.5 \%$ & 24 \\
\hline $\begin{array}{l}\text { Chronic HBV with elevated ALT to } \\
\text { compensated cirrhosis }\end{array}$ & $3.8 \%$ & $0.5-12.3 \%$ & 24 \\
\hline Chronic HBV with elevated ALT to HCC & $1.5 \%$ & $0.5-9.5 \%$ & 24 \\
\hline $\begin{array}{l}\text { Durable virologic response while on } \\
\text { treatment }\end{array}$ & $15.0 \%$ & $5.0-30.0 \%$ & 24 \\
\hline Receiving treatment with durable response & $50.0 \%$ & $0.0-100 \%$ & 24 \\
\hline Durable response relapse to elevated ALT & $7.0 \%$ & $2.0-15.0 \%$ & 24 \\
\hline Durable response relapse to $\mathrm{HCC}$ & $0.3 \%$ & $0.2-0.5 \%$ & 24 \\
\hline Compensated to decompensated cirrhosis & $7.0 \%$ & $3.0-10.0 \%$ & 24 \\
\hline Mortality from compensated cirrhosis & $4.8 \%$ & $2.0-13.1 \%$ & 24 \\
\hline Mortality from decompensated cirrhosis & $17.3 \%$ & $5.8-22.1 \%$ & 24 \\
\hline Cirrhosis to $\mathrm{HCC}$ & $3.3 \%$ & $1.0-11.3 \%$ & 24 \\
\hline $\begin{array}{l}\text { Liver transplantation for decompensated } \\
\text { cirrhosis }\end{array}$ & $1.5 \%$ & $0.0-40.0 \%$ & 24 \\
\hline Mortality from HCC & $40.0 \%$ & $32.0-47.3 \%$ & 24 \\
\hline Liver transplantation for $\mathrm{HCC}$ & $0.1 \%$ & $0.0-40.0 \%$ & 24 \\
\hline Mortality first year after liver transplantation & $15.0 \%$ & $7.5-30.0 \%$ & 24 \\
\hline $\begin{array}{l}\text { Mortality second and subsequent years after } \\
\text { liver transplantation }\end{array}$ & $1.5 \%$ & $0.8-3.0 \%$ & 24 \\
\hline \multicolumn{4}{|c|}{ Health-state utility weights for quality of life adjustments } \\
\hline Normal ALT & 1.00 & $0.95-1.00$ & 24 \\
\hline Elevated ALT & 0.99 & $0.90-1.00$ & 24 \\
\hline Durable response & 1.00 & $0.90-1.00$ & 24 \\
\hline
\end{tabular}




\begin{tabular}{llll}
\hline Variable & Base case & Range & Ref. \\
\hline Compensated cirrhosis & 0.80 & $0.70-0.93$ & 24 \\
Decompensated cirrhosis & 0.60 & $0.50-0.70$ & 24 \\
HCC & 0.73 & $0.50-0.80$ & 24 \\
Liver transplantation & 0.86 & $0.70-0.90$ & 24 \\
\hline
\end{tabular}

2 ALT: alanine aminotransferase; HBV: hepatitis B virus; HCC: hepatocellular carcinoma; IP:

3 immunoprophylaxis; LAM: lamivudine; LdT: telbivudine; TDF: tenofovir.

4 †Prevention efficacy of LAM was assumed to not be superior to LdT. 


\section{Table 2(on next page)}

Cost variables for base-case and sensitivity analysis 


\begin{tabular}{|c|c|c|c|}
\hline Variable & $\begin{array}{l}\text { Base case } \\
\text { (USD) }\end{array}$ & $\begin{array}{l}\text { Range } \\
\text { (USD) }\end{array}$ & Ref. \\
\hline Hepatitis $B$ vaccination, three times & $\$ 3.0$ & $\$ 1.5-6.0$ & 59 \\
\hline Hepatitis B immunoglobulin administration & $\$ 40.0$ & $\$ 20.0-80.0$ & 58,59 \\
\hline LAM, daily ${ }^{\dagger}$ & $\$ 2.5$ & $\$ 1.3-5.0$ & 60 \\
\hline $\mathrm{LdT}$, daily ${ }^{\dagger}$ & $\$ 3.6$ & $\$ 1.8-7.2$ & 60 \\
\hline TDF, daily ${ }^{\dagger}$ & $\$ 8.7$ & $\$ 4.4-17.4$ & 61 \\
\hline $\begin{array}{l}\text { Ratio of proportion of mothers with }<6 \text { to }>6 \\
\log _{10} \text { copies } / \text { mL HBV-DNA }\end{array}$ & 0.136 & $0.068-0.273$ & 57 \\
\hline HBV-DNA quantification & $\$ 16.3$ & $\$ 8.2-32.6$ & 60 \\
\hline HBV-marker test & $\$ 3.3$ & $\$ 1.6-6.6$ & 60 \\
\hline Chronic hepatitis B, annual $^{\#}$ & $\$ 1,780$ & $\$ 890-3,560$ & 63 \\
\hline Compensated cirrhosis, annual & $\$ 2,759$ & $\$ 1,380-5,518$ & 63 \\
\hline Decompensated cirrhosis, annual & $\$ 5,130$ & $\$ 2,565-10,260$ & 63 \\
\hline Hepatocellular carcinoma, annual & $\$ 7,302$ & $\$ 3,651-14,604$ & 63 \\
\hline Liver transplantation, first year & $\$ 37,458$ & $\$ 18,729-74,916$ & 62 \\
\hline $\begin{array}{l}\text { Liver transplantation, second and subsequent } \\
\text { years, annual }\end{array}$ & $\$ 3,276$ & $\$ 1,638-6,552$ & 62 \\
\hline Discount rate, annual & $3 \%$ & $0-5 \%$ & - \\
\hline
\end{tabular}

2 HBV: hepatitis B virus; LAM: lamivudine; LdT: telbivudine; TDF: tenofovir; USD: US Dollar.

3 Administered from week 28 of gestation to 4 weeks after delivery.

$4 \quad \# 50 \%$ of patients with durable response were assumed to continue receiving treatment. 


\section{Table $\mathbf{3}$ (on next page)}

Short-term outcomes 
1

\begin{tabular}{lccccc}
\hline Strategy & $\begin{array}{c}\text { Infections } \\
(\boldsymbol{n})\end{array}$ & $\begin{array}{c}\text { Incremental } \\
\text { infections averted } \\
(\boldsymbol{n})\end{array}$ & $\begin{array}{c}\text { Cost } \\
(\text { USD) }\end{array}$ & $\begin{array}{c}\text { Incremental cost } \\
\text { (USD) }\end{array}$ & ICER \\
\hline IP & 1,727 & - & $\$ 239,000$ & - & - \\
LAM + IP & 284 & 1,443 & $\$ 3,078,568$ & $\$ 2,839,568$ & 1,967 \\
LdT + IP & 167 & 117 & $\$ 4,147,944$ & $\$ 1,069,376$ & 9,178 \\
TDF + IP & 167 & 0 & $\$ 9,105,960$ & $\$ 4,958,016$ & - \\
\hline
\end{tabular}

2 ICER: incremental cost-effectiveness ratio (US dollars per incremental infection averted); IP: immunoprophylaxis;

3 LAM: lamivudine; LdT: telbivudine; TDF: tenofovir; USD; US Dollar.

4 


\section{Table 4(on next page)}

Long-term outcomes 
1

\begin{tabular}{lccccccc}
\hline Strategy & $\begin{array}{c}\text { HCC } \\
(\boldsymbol{n})\end{array}$ & $\begin{array}{c}\text { HBV- } \\
\text { related } \\
\text { deaths } \\
(\boldsymbol{n})\end{array}$ & $\begin{array}{c}\text { QALY } \\
\text { s }\end{array}$ & $\begin{array}{c}\text { Incrementa } \\
\text { I QALYs }\end{array}$ & $\begin{array}{c}\text { Cost } \\
\text { (USD) }\end{array}$ & $\begin{array}{c}\text { Incremental } \\
\text { cost } \\
\text { (USD) }\end{array}$ & $\begin{array}{c}\text { ICER } \\
(\mathbf{9 5 \%} \text { CI) }\end{array}$ \\
\hline IP & 385 & 304 & 292,167 & - & $\$ 4,897,077$ & - & Dominated \\
TDF+IP & 37 & 29 & 295,664 & - & $\$ 9,556,428$ & - & Dominated \\
LAM+IP & 63 & 50 & 295,403 & - & $\$ 3,843,301$ & - & - \\
LdT+IP & 37 & 29 & 295,664 & 261 & $\$ 4,598,412$ & $\$ 755,111$ & $\$ 2,891$ \\
& & & & & & & $(-\$ 932 \sim \$ 20,372)$ \\
\hline
\end{tabular}

2 CI: confidence interval; HBV: hepatitis B virus; HCC: hepatocellular carcinoma; ICER: incremental cost-

3 effectiveness ratio (US Dollar per quality-adjusted life year gained); IP: immunoprophylaxis; LAM: lamivudine;

4 LdT: telbivudine; QALY: quality-adjusted life year; TDF: tenofovir; USD; US Dollar.

5 